\title{
Roosting records in tree cavities by a forest-dwelling bat species (Histiotus magellanicus) in Andean temperate ecosystems of southern Chile
}

\author{
Registro de utilización de cavidades de árboles como refugios por un murciélago de bosque \\ (Histiotus magellanicus) en ecosistemas templados andinos del sur de Chile
}

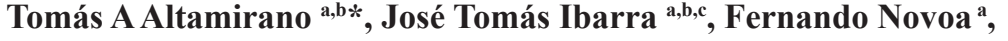 \\ Alejandra Vermehren ${ }^{a}$, Kathy Martin ${ }^{\text {b,d }}$, Cristián Bonacic ${ }^{a}$ \\ *Corresponding author: ${ }^{\text {a }}$ Pontificia Universidad Católica de Chile, School of Agriculture and Forest Sciences, \\ Department of Ecosystems and Environment, Fauna Australis Wildlife Laboratory, Vicuña Mackenna 4860 PC 7820436, \\ Santiago, Metropolitan Region, Chile, tel.: 562 23544169, taaltami@uc.cl \\ ${ }^{\mathrm{b}}$ University of British Columbia, Department of Forest and Conservation Sciences, Centre for Applied Conservation Research, \\ 2424 Main Mall, V6T 1Z4 Vancouver, British Columbia, Canada. \\ ${ }^{\mathrm{c}}$ Pontificia Universidad Católica de Chile, Villarrica Campus, Centre for Local Development, Education and Interculturality \\ (CEDEL), Bernardo O’Higgins 501, Villarrica, La Araucanía Region, Chile. \\ ${ }^{\mathrm{d}}$ Environment and Climate Change Canada, Pacific Wildlife Research Centre, 5421 Robertson Road, V4K 3N2 Delta, \\ British Columbia, Canada.
}

\begin{abstract}
SUMMARY
Tree cavities can provide critical roosting sites for cavity-using vertebrates. These sites can directly affect productivity and survival of bats. Histiotus magellanicus, one of the bat species with the southernmost distribution in the world, is suspected to use tree cavities, under bark, caves and human buildings for roosting. We document the first records of this bat roosting in tree cavities created by both cavity-facilitators (i.e., excavators) and tree-decay processes on standing dead and large decaying trees in Andean temperate forests, southern Chile. Our records contribute to improve current knowledge of roosting habitat of $H$. magellanicus. We discuss these natural history records on roosting site selection and the potential importance of tree cavities for this species in southern temperate ecosystems.
\end{abstract}

Key words: cavity-facilitator, Histiotus magellanicus, Pygarrhichas albogularis, snags, Southern Big-eared Brown Bat.

\section{RESUMEN}

Las cavidades en árboles pueden proveer importantes sitios de refugio para vertebrados que utilizan cavidades. Estos sitios pueden afectar directamente la productividad y sobrevivencia de murciélagos. Histiotus magellanicus, una de las especies de murciélago con la distribución más austral en el mundo, supuestamente se refugia en cavidades de árboles, bajo la corteza, en cuevas y en construcciones humanas. En este trabajo documentamos los primeros registros de esta especie refugiándose en cavidades de árboles, que fueron creadas por excavación y por procesos de descomposición, en árboles muertos en pie y vivos en estado de descomposición avanzado en los bosques templados andinos, sur de Chile. Nuestros registros contribuyen a ampliar el actual conocimiento de refugios utilizados por H. magellanicus. Discutimos estos registros de historia natural sobre selección de sitios de refugio y el potencial rol de cavidades de árboles para esta especie en los ecosistemas templados del sur de Sud América.

Palabras clave: árboles muertos, facilitador de cavidades, Histiotus magellanicus, murciélago café orejudo del sur, Pygarrhichas albogularis.

\section{INTRODUCTION}

Most of the 1300 bat species in the world use tree cavities, caves and human buildings for roosting (Iriarte 2008, Voigt and Kingston 2016). Roosting sites are critical habitat structures because most bat species spend at least $50 \%$ of their time inside these sites (Kunz 1982). Bat productivity and survival can depend directly on the quantity and quality of roosting sites (O'Donnell and Sedgeley 2006). Bat populations may be limited by shortage of suitable sites for roosting in degraded and deforested ecosystems (Mickleburgh et al. 2002, Evelyn and Stiles 2003). Indeed, land use change has been reported as the most important threat for bat species; specifically, forest loss has the highest relative importance (50 \%) among threats for bat conservation (Voigt and Kingston 
2016). Bats are secondary cavity-users that roost either in excavated cavities (i.e., created by cavity-facilitators) or in those produced by tree decay processes (Martin and Eadie 1999). For example, $73 \%$ of the cavities used for roosting by Eptesicus fuscus Palisot de Beauvois 1796 were facilitated by sapsuckers and woodpeckers in Saskatchewan, Canada (Kalcounis and Brigham 1998). On the other hand, in New Zealand, $100 \%$ of the cavities used for roosting by Chalinolobus tuberculatus Forster 1844 were located in decay-formed cavities (Sedgeley and O'Donnell 1999). These cavity creation processes could play an important role on roosting site facilitation for bat species.

Histiotus magellanicus Philippi 1866, one of the 13 bat species present in Chile, has the southernmost distribution in the world (Mann 1978, Ossa et al. 2014, Sierra-Cisternas and Rodriguez-Serrano 2015). This insectivorous bat is endemic to temperate forests of South America, inhabiting Chile and Argentina from $36^{\circ}$ to $55^{\circ}$ south latitude (Mann 1978, Massoia and Chebez 1993, Ossa and Díaz 2014). It has been suggested that $H$. magellanicus uses tree cavities, under bark, caves and human buildings for roosting (Muñoz-Pedreros and Yañez 2000, Galaz and Yañez 2006). However, confirmed roosting records for this austral bat are still lacking (Giménez et al. 2012, Ossa and Díaz 2014). This species has a distinctive tolerance to low temperatures in austral regions, entering into winter torpor inside roosting sites to survive adverse conditions (Massoia and Chebez 1993, Galaz and Yañez 2006). Treecavities provide protection against fluctuations in ambient temperature, humidity and predators (Kunz 1982). Thus, the availability of suitable cavities for roosting in areas undergoing rapid degradation and deforestation could play an important role in the ecology and persistence of this species. Here, we document the first confirmed records of H. magellanicus roosting in tree cavities. Specifically, this study provides a detailed characterization of roosting site selection at three scales (i.e., cavity, tree and stand) in Andean temperate forests.

\section{METHODS}

We searched for nests and/or roosting sites at 15 forest stands (each with an area of at least 20 ha) in Andean temperate forests of La Araucanía Region, Chile (39¹6'28' S, $51^{\circ} 53$ '23" W). During two breeding seasons (2015-2016 and 2016-2017), we spent about six hours daily, six days per week, from November to January looking for nests or roosting sites of cavity-using vertebrate species.

When we found a cavity being used by a bat, we monitored this cavity every 3-4 days utilizing a video camera cavity-monitoring system. By the end of the field season, we quantified roosting site characteristics at three scales: (a) cavity-scale: origin (excavated or decay-formed processes), height, entrance orientation, cavity entrance width and height, vertical and horizontal depth; (b) tree-scale: tree species, diameter at breast height $(\mathrm{DBH})$, diameter at cavity height $(\mathrm{DCH})$, vine and epiphyte cover, decay stage of roosting tree (decay classes: 1: live and healthy tree; 2 : live and unhealthy tree; 3 : standing dead tree in progressive states of decay; adapted from Thomas et al. 1979); (c) stand-scale: forest successional stage (early $=4-35$ years old; mid $=36-100$ years old; late $=>100$ years old), slope, canopy cover, understory cover, density of trees with $\mathrm{DBH}>12.5 \mathrm{~cm}$, signs of recent human activity (grazing, fire and logging).

\section{RESULTS}

On 25 November 2015, we found an individual of $H$. magellanicus roosting in a tree cavity previously excavated by Pygarrhichas albogularis (King, 1831: Furnariidae) for nesting. The bat species was identified based on its body size, dark color, the length of the ears $(<25 \mathrm{~mm})$ and the distinct "ventral decubitus" rest position (Galaz and Yañez 2006, Díaz et al. 2011; figure 1A). The tree cavity was located in a standing dead Lophozonia obliqua (Mirb.) Heenan et Smissen tree (= Nothofagus obliqua (Mirb.) Oerst.). The tree was in an advanced stage of decay (i.e., broken top, no branches, $<75 \%$ of bark and rotten soft wood; figure 1A) (table 1, roost 1). We did not record a bat roosting in this cavity during subsequent cavity checks: eight checks between 29 November 2015 and 18 January 2016, and four checks between 25 November 2016 and 26 December 2016.

On 05 November 2016, we registered six H. magellanicus roosting in a decay-formed tree cavity available in a Nothofagus dombeyi tree (Mirb.) Oerst. (figure 1B) (table 1 , roost 2 ). In contrast to the previous excavated cavity, the interior chamber was facing up from the entrance in the decay-formed one. Four days later (09 November), four individuals were roosting in the cavity. On 12 November, we did not record any individual inside the cavity; on 16 November was the last time we recorded individuals (four) roosting in this cavity. During the following cavity checks (21, 24 and 28 November, and 01, 05, 09, 14, 16, 19, 23, and 28 December) we did not record any bat inside the cavity.

On 26 December 2016, we recorded three individuals of $H$. magellanicus roosting in a decay-formed cavity in a L. obliqua tree (figure 1C) (table 1, roost 3). On 28 December 2016, we found 10 adults and five pups of $H$. magellanicus roosting in a decay-formed cavity in a standing dead $N$. dombeyi tree (figure 1D) (table 1, roost 4). We never recorded bats inside this cavity in 2015-2016 and 2016-2017, despite there were 28 and 11 previous visits to this tree cavity respectively.

\section{DISCUSSION}

Our records contribute to improve current knowledge of roosting habitat of $H$. magellanicus in southern tem- 


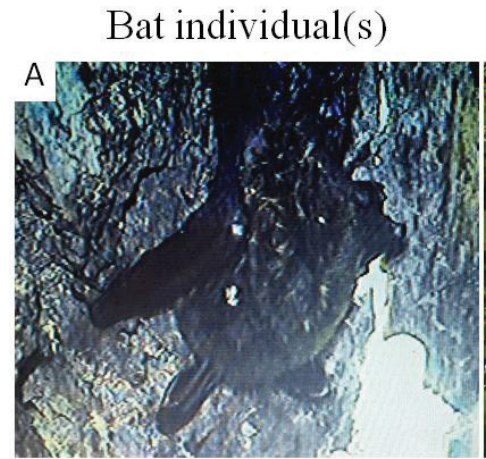

\section{Tree cavity}
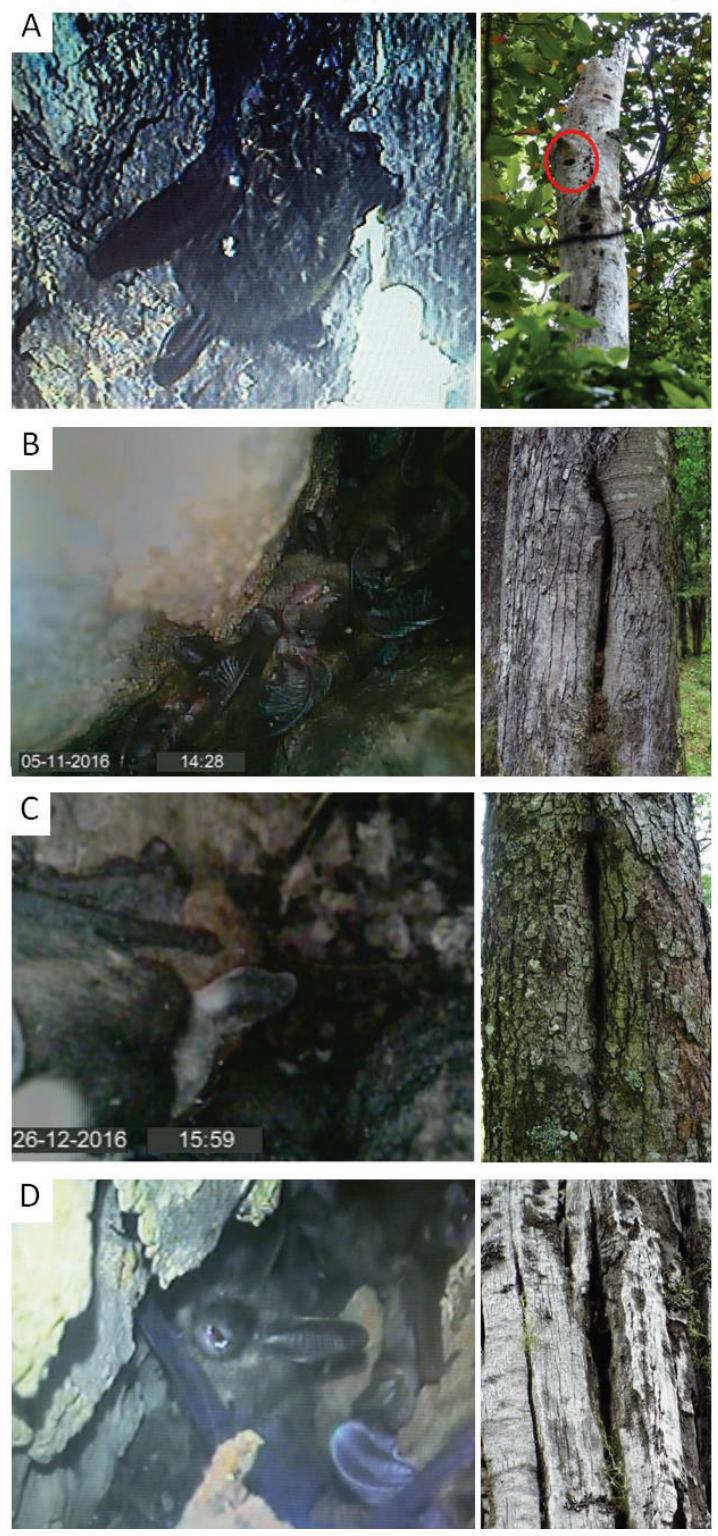

Figure 1. Histiotus magellanicus roosting in tree cavities in Andean temperate forests, southern Chile. Bat individual roosting in an excavated tree cavity in a standing dead Lophozonia obliqua tree (A). Bat individuals roosting in a decay-formed cavity in a live decaying Nothofagus dombeyi tree (B). Bat individuals roosting in a decay-formed cavity in a live decaying Lophozonia obliqua tree (C). Bat individuals roosting in a decay-formed cavity in a dead standing Nothofagus dombeyi tree (D).

Histiotus magellanicus refugiándose en cavidades de árboles en los bosques templados andinos, sur de Chile. Murciélago refugiándose en una cavidad excavada en un Lophozonia obliqua muerto en pie (A). Murciélagos refugiándose en una cavidad formada por descomposición en un Nothofagus dombeyi vivo no sano (B). Murciélagos refugiándose en una cavidad formada por descomposición en un Lophozonia obliqua vivo no sano $(\mathrm{C})$. Murciélagos refugiándose en una cavidad formada por descomposición en un Nothofagus dombeyi muerto en pie (D). perate forests (Sierra-Cisternas and Rodriguez-Serrano 2015). Roosting bats used cavities formed by excavation and tree decay. The use of cavities formed by these two processes is similar to the one reported for four forestdwelling bats (E. fuscus, Lasionycteris noctivagans Le Conte 1831, Myotis evotis H. Allen 1864 and Myotis volans $\mathrm{H}$. Allen 1866) in northern temperate forests, where $76 \%$ were decay-formed cavities and $24 \%$ were cavities excavated by woodpeckers (Vonhof and Barclay 1996). Most tree-cavities (73 \%) used for roosting by E. fuscus were excavated by sapsuckers and woodpeckers in Saskatchewan, Canada (Kalcounis and Brigham 1998). In southern temperate forests, $P$. albogularis, an endemic relatively small body-sized bird species (25.6 g) (Ibarra and Martin 2015), could play an important role as cavity facilitator in secondary and disturbed forest-stands, where the density of tree-cavities is 2.5 times lower than in old-growth forests (Altamirano 2014).

The fact that $H$. magellanicus was recorded roosting in standing dead and large decaying trees, coincides with the pattern documented for other forest-dwelling bat species, which used the largest trees available in their stands as roosting sites (Lewis 1995). For example, all trees used for roosting by $\mathrm{H}$. magellanicus were larger than the average tree-size available in their stands (average $\mathrm{DBH}=22.2 \mathrm{~cm}$, Altamirano 2014). Furthermore, bats were found roosting in standing dead trees in $50 \%$ of our roosting records; despite trees in this decay stage represent only $12 \%$ of total trees available in their stands (Altamirano 2014). These structural components may be essential "habitat legacies" (Perry and Amaranth 1997), for forest-dwelling bats inhabiting southern temperate forests. With forest loss as the main threat for many bat species (Voigt and Kingston 2016 ), and with only $30 \%$ of the original vegetation cover remaining in temperate forests of South America (Myers et al. 2000), our few records could be suggesting an important role of standing dead and large decaying trees for $H$. magellanicus populations.

Histiotus magellanicus inhabits the whole distribution of temperate forests of South America (Mann 1978, Massoia and Chebez 1993, Ossa and Díaz 2014). These forests include the seasonally irruptive and topographically complex Andean ecosystems located at the southern cone of the continent. In these locations, roosting in tree cavities may provide a reliable protection to deal with adverse climatic conditions (e.g., low temperatures, snow and storms). However, further research is needed to better understand the patterns of tree cavity-roosting of $H$. magellanicus and other sympatric forest-dwelling bats in southern temperate ecosystems (e.g., Lasiurus varius Poeppig 1835, Myotis chiloensis Waterhouse 1840, Tadarida brasiliensis I. Geoffroy 1824; Mann 1978). The costs and benefits of roosting, and likely breeding, in excavated or decay-formed tree cavities by bats also provide fruitful avenues for further studies. 
Table 1. Characteristics of roosting sites (at three scales: cavity, tree and stand) used by Histiotus magellanicus in Andean temperate forests, Chile. Andinos, Chile.

Características de los sitios de refugio (a tres escalas: cavidad, árbol y rodal) usados por Histiotus magellanicus en los bosques templados

\begin{tabular}{|c|c|c|c|c|}
\hline VARIABLE & Roost 1 & Roost 2 & Roost 3 & Roost 4 \\
\hline \multicolumn{5}{|l|}{ Cavity } \\
\hline Origin & Excavated* & Decay-formed & Decay-formed & Decay-formed \\
\hline Cavity height (m) & 8.3 & 1.6 & 1.4 & 6.9 \\
\hline Entrance orientation $\left(^{\circ}\right)$ & 180 & 257 & 188 & 260 \\
\hline Entrance width $(\mathrm{cm})$ & 5.0 & 3.0 & 2.5 & 2.0 \\
\hline Entrance height $(\mathrm{cm})$ & 4.0 & 18.0 & 43.0 & 8.0 \\
\hline Horizontal cavity depth $(\mathrm{cm})$ & 7.0 & 11.0 & 11.0 & 11.0 \\
\hline Vertical cavity depth (cm) & 15.0 & 51.0 & 13.0 & 15.0 \\
\hline \multicolumn{5}{|l|}{ Tree } \\
\hline Species & L. obliqua & N. dombeyi & L. obliqua & N. dombeyi \\
\hline Diameter at cavity height $(\mathrm{cm})$ & 28.0 & 41.4 & 58.9 & 70.0 \\
\hline Diameter at breast height $(\mathrm{cm})$ & 28.6 & 43.2 & 59 & 77.6 \\
\hline Decay class & 3 & 2 & 2 & 3 \\
\hline Vine and epiphyte cover (\%) & 0.0 & 0.0 & 0.0 & 0.0 \\
\hline \multicolumn{5}{|l|}{ Stand } \\
\hline Type & Mid-successional & Mid-successional & Mid-successional & Mid-successional \\
\hline Slope $(\%)$ & 23 & 23 & 0 & 0 \\
\hline Canopy cover $(\%)$ & 80 & 55 & 80 & 10 \\
\hline Understory cover $(\%)$ & 65 & 20 & 35 & 10 \\
\hline Tree density $(\# / H a)$ & 1,473 & 609 & 102 & 279 \\
\hline Signs of human impact ${ }^{\Delta}$ & $\mathrm{G}, \mathrm{F}$ & $\mathrm{G}, \mathrm{F}, \mathrm{L}$ & G & $\mathrm{G}, \mathrm{F}, \mathrm{L}$ \\
\hline
\end{tabular}

* Cavity excavated by Pygarrhichas albogularis. ${ }^{\wedge} \mathrm{G}$ : Grazing, F: Fire, and L: Logging.

\section{ACKNOWLEDGMENTS}

This study was supported by Rufford Small Grants for Nature Conservation (14397-2), Vicerrectoría de Investigación from the Pontificia Universidad Católica de Chile (Internationalization Grant Agreement PUC1566-MINEDUC), and "NETBIOAMERICAS" CONICYT/Apoyo a la Formación de Redes Internacionales entre Centros de Investigación (REDES150047), and CONICYT/FONDECYT de Inicio (11160932). We thank H. Jaillard, J. Lee, R. Godoy, C. Rivas, F. Villalobos, L. Iturra, P. Aspillaga, G. Gómez, V. Salinas, A. Contador for valuable assistance in the field during the 2015-2016 and 2016-2017 breeding seasons. TAA is supported by Comisión Nacional de Investigación Científica y Tecnológica (CONICYT, award number 74160073).

\section{REFERENCES}

Altamirano TA. 2014. Breeding ecology of cavity-nesting birds in the Andean temperate forest of southern Chile. PhD Dis- sertation. Santiago. Chile. Department of Ecosystems and Environment, School of Agriculture and Forest Sciences, Pontificia Universidad Católica de Chile. 145 p.

Díaz MM, LF Aguirre, RM Barquez. 2011. Clave de identificación de los murciélagos del cono sur de Sudamérica. Cochabamba, Bolivia. Imprenta ETREUS. 94 p.

Evelyn MJ, DA Stiles. 2003. Roosting requirements of two frugivorous bats (Sturnira lilium and Arbiteus intermedius) in fragmented Neotropical forest. Biotropica 35(3): 405-418.

Galaz JL, Yañez J. 2006. Los murciélagos de Chile: Guía para su reconocimiento. Santiago, Chile. Ediciones del Centro de Ecología Aaplicada. 80 p.

Giménez AL, NP Giannini, MI Schiaffini, GM Martin. 2012. New records of the rare Histiotus magellanicus (Chiroptera, Vespertilionidae) and other bats from central Patagonia, Argentina. Mastozoología Neotropical 19(2): 213-224.

Ibarra JT, K Martin. 2015. Biotic homogenization: Loss of avian functional richness and habitat specialists in disturbed Andean temperate forests. Biological Conservation 192: 418-427.

Iriarte A. 2008. Mamíferos de Chile. Barcelona, España. Lynx Edicions. 420 p. 
Kalcounis MC, RM Brigham. 1998. Secondary use of aspen cavities by tree-roosting big brown bats. Journal of Wildlife Management 62: 603-611.

Kunz TH. 1982. Roosting Ecology of Bats. In Kunz TH ed. Ecology of Bats. New York, USA. Plenum Publishing Corporation. p. 1-55.

Lewis SE. 1995. Roost fidelity of bats: a review. Journal of Mammalogy 76: 481-496.

Mann G. 1978. Los pequeños mamíferos de Chile: marsupiales, quirópteros, edentados y roedores. Santiago, Chile. Editorial Universitaria. 342 p.

Martin K, JM Eadie. 1999. Nest webs: a community-wide approach to the management and conservation of cavity-nesting forest birds. Forest Ecology and Management 115(2): 243-257.

Massoia E, JC Chebez. 1993. Mamíferos silvestres del archipiélago fueguino. Buenos Aires, Argentina. L.O.L.A. 261 p.

Mickleburgh SP, AM Hutson, PA Racey. 2002. A review of the global conservation status of bats. Oryx 36(1): 18-34.

Muñoz-Pedreros A, J Yañez. 2000. Mamíferos de Chile. Temuco, Chile. Ediciones Centro de Estudios Agrarios. 464 p.

Myers N, Mittermeier RA, CG Mittermeier, GA da Fonseca, J Kent. 2000. Biodiversity hotspots for conservation priorities. Nature 403(6772): 853-858.

O'Donnell CF, JA Sedgeley. 2006. Causes and consequences of tree-cavity roosting in a temperate bat, Chalinolobus tuberculatus, from New Zeland. In Zubaid A, McCracken GF, Kunz TH eds. Functional and Evolutionary Ecology of Bats. Oxford, UK. Oxford University Press. p. 308-328.

Ossa G, C Bonacic, RM Barquez. 2014. First record of Histio- tus laephotis (Thomas, 1916) from Chile and new distributional information for Histiotus montanus (Phillipi and Landbeck, 1861) (Chiroptera, Vespertilionidae). Mammalia 79(4): 457-461.

Ossa G, F Díaz. 2014. Histiotus magellanicus (Philippi 1866), un ignorado dentro de la mastofauna chilena. La Chiricoca 17: 4-6.

Perry DA, MP Amaranth. 1997. Disturbance, recovery, and stability. In Kohm KA, Franklin JF eds. Creating a forestry for the 21 st century, the science of ecosystem management. Washington DC, USA. Island Press. p. 31-56.

Sedgeley JA, CF O'Donnell. 1999. Roost selection by the longtailed bat, Chalinolobus tuberculatus, in temperate New Zealand rainforest and its implications for the conservation of bats in managed forests. Biological Conservation 88(2): 261-276.

Sierra-Cisternas C, E Rodriguez-Serrano. 2015. Los quirópteros de Chile: avances en el conocimiento, aportes para la conservación y proyecciones futuras. Gayana 79(1): 57-67.

Thomas JW, RG Anderson, C Maser, EL Bull. 1979. Snags. In Thomas JW ed. Wildlife habitats in managed forests: the Blue Mountains of Oregon and Washington. Washington DC, USA. U.S.D.A. Forest Service Agriculture Handbook No. 553. p. 66-77.

Voigt CC, T Kingston. 2016. Bats in the anthropocene: conservation of bats in a changing world. New York, USA. Springer Open. $606 \mathrm{p}$.

Vonhof MJ, RMR Barclay. 1996. Roost-site selection and roosting ecology of forest-dwelling bats in southern British Columbia. Canadian Journal of Zoology 74(10): 1797-1805. 
